\title{
IMPACT OF EXCHANGE RATE DERIVATIVES ON STOCKS IN EMERGING MARKETS
}

\author{
L. Arturo BERNAL-PONCE (D)1, Claudia Estrella CASTILLO-RAMÍREZ (D)2, \\ Francisco VENEGAS-MARTÍNEZ (D) ${ }^{3 *}$ \\ ${ }^{1}$ Business School, Tecnologico de Monterrey, Guadalajara, México \\ ${ }^{2}$ Escuela de Ciencias Económica y Empresariales, Universidad Panamericana, \\ Ciudad de México, México \\ ${ }^{3}$ Escuela Superior de Economía, Instituto Politécnico Nacional, Ciudad de México, México
}

Received 24 March 2019; accepted 27 January 2020

\begin{abstract}
This paper investigates the effect of derivatives on the relationship between the foreign exchange rate and the stock market. A theoretical model is used to extend the understanding of that relationship. Also, the model is tested with an empirical analysis using the GMM strategy for the Mexican and Brazilian stock markets for the period 2007 to 2019. Findings reveal that in addition to the spot exchange rate, exchange rate futures explain the currency exposure, wherein the derivative effect is the most prominent. The result implies that both risk sources should be considered in the implementation of risk management or macroeconomic policy. The theoretical results are extended by applying them to international portfolio management, proposing a strategy to mitigate foreign exchange exposure with derivatives. This study contributes to the literature by explaining why the minimum variance hedge ratio plays an essential role in the foreign exchange rate and stock market nexus.
\end{abstract}

Keywords: dynamic stochastic programming, portfolio, risk hedging, derivatives, futures market, foreign assets, foreign exchange markets.

JEL Classification: C61, G11, G13, G15.

\section{Introduction}

International finance theory states that unsystematic risk may be reduced by increasing the number of foreign stocks in a portfolio (Salma \& Hussain, 2018). Nevertheless, the exchange rate risk must be considered. Several studies have proved that variations in the exchange rates affect the present and expected profits of cross-border firms, such as importers-exporters, manufacturing industries, and multinational enterprises. As a result, there is a plausible impact on expected cash flows. On the other hand, according to efficient market theory, a firm

${ }^{\star}$ Corresponding author. E-mail: fvenegas1111@yahoo.com.mx 
stock price is an unbiased estimate of the real value of the investment. The latter implies an exchange rate effect on stock prices or firm value. In this regard, several empirical studies have found either a weak or no substantial relationship between the exchange rate and stock prices (Jorion, 1990; He \& Ng, 1998; Nguyen et al., 2007; Makar \& Huffman, 2008; Lee \& Suh, 2012; Inci \& Lee, 2014). In a multinational context, an explanation for this puzzling weak relationship is that firms have been hedging their exchange rate risk using foreign currency derivatives (Kambi \& Ali, 2016; Singh, 2017; Caves, 2007; Allayannis \& Ofek, 2001).

Some authors have performed empirical studies to analyze the effect of hedging strategies with derivatives on firm value (Guay \& Kothari, 2003; Bartram et al., 2011), or on portfolio allocation (Demange \& Laroque, 1999; Branger et al., 2019). Findings have proved the negative effect of the lack of hedging practices on exchange rate exposure (Bhargava \& Malhotra, 2007), suggesting that exchange rate exposure is negatively related to derivatives usage (Anderson et al., 2004). However, the impact of exchange rate derivatives on the entire stock market has only been analyzed using derivative volume as a proxy of the derivative market (Aysun \& Guldi, 2011). A detailed analysis that explains why foreign exchange derivatives moderate the effect of the relationship between the exchange rate and stock markets is lacking, particularly a study with a strong theoretical basis. This paper aims to contribute to that discussion with a theoretical and empirical analysis not only by explaining the causes and magnitude of the impact but also by developing a theoretical solution that may also have a risk management application. Findings would help to extend the understanding of the sources of uncertainty in an exchange rate market, which would allow more accurate currency risk management strategies.

To that end, a stochastic model in continuous time is performed for an investor who has access to a portfolio of foreign stock and exchange rate derivatives. The model is tested by performing a panel econometric analysis using the Generalized Method of Moments (GMM) strategy for the Mexican and Brazilian stock markets. There are several reasons why the study has been carried out for the Mexican and Brazilian stock markets: First; during and after the 2008 financial crisis, high exchange rate depreciation in Latin America was observed. For example, between September and March of that year, the five biggest Latin America economies experienced a considerable depreciation in their currencies, e.g., México and Brazil saw 38.1\% and 41.7\%, respectively. Second; Duarte and Mascareñas (2014) show that the major Latin American economies have experienced a change from non-efficiency to market efficiency in recent years, which is an important feature in empirical analysis on stock returns, and is the case for this research. Third; the currency futures of those two countries are quoted in the Chicago Mercantile Exchange market, a feature that is used in this study because instantaneous changes in those prices are appropriate for the analysis of a dynamic stochastic model like the model described in this study.

The main contribution of this research is to extend the theory that explains the impact of foreign currency on stock markets, considering the moderating effect of the derivative market. Based on the theoretical model, this analysis reveals why that relationship has two components: the spot and the futures exchange rate markets. It also explains how the hedge ratio, or the correlation between a derivative and the spot exchange rate, plays an essential role in that nexus. In addition, following the theoretical result, the international portfolio 
theory is extended by proposing an optimal hedging strategy on currency risk. In particular, a closed-form solution is proposed that estimates the optimal weights to hedge the foreign exchange risks in an international portfolio context. The rest of the paper is organized as follows: Section 1 provides the literature review. Section 2 describes the theoretical model. Section 3 describes the data and develops the econometric analysis. Section 4 discusses the results. The final section provides conclusions and acknowledges limitations.

\section{Literature review}

\subsection{Foreign exchange impact on stock markets}

The impact of the exchange rate on stock markets has been defined in literature as economic exposure or exchange rate exposure. Most empirical analyses have followed Adler and Dumas's approach (1983) estimating exposure by the regression coefficient of the exchange rate change on stock returns. In the same sense, Inci and Lee (2014) performed a causality analysis and found a bidirectional causal relationship from exchange rates to stock returns before 2008. In the same study, the result proved to be stronger during the 2008 recession.

In the context of a multinational firm, this finding of exposure suggests that the effect of the exchange rate on stock returns depends on the firm's characteristics, for example, the degree of foreign involvement (Jorion, 1990). Some studies show evidence that exposure is time-variant, and depends on factors like financial distress, growth opportunities, and product uniqueness (Wei \& Starks, 2013). In a similar approach, Anisak and Mohamad (2019) emphasize that exchange rate exposure depends on when it is measured, arguing that the results depend on if exposure is measured before or after a crisis, which was corroborated by Mahapatra and Bhaduri (2019). Finally, some analyses show evidence that exposure is less significant for short-term periods due to restrictions on the currency's daily trading band and that it is more substantial for longer periods (Tang, 2019).

Regarding Latin American firms, a study for all economic sectors confirms previous findings of an adverse effect of exchange on stock returns, except for Colombia (Santillán-Salgado et al., 2019). For Brazilian companies, Rossi's (2011) study found that the exchange rate exposure changed when Brazil changed from a fixed to a floating regime, wherein foreign currency borrowing and the use of derivatives were essential factors.

\subsection{Foreign exchange derivatives as moderators of foreign exchange exposure}

Empirical literature analyzing the use of foreign derivatives by firms has emphasized that exposure is negatively correlated to derivative usage. This can be seen in a research for the emerging economies: Brazil, Chile, Israel, Korea, Mexico, and Turkey, developed by Aysun and Guldi (2011), in which the volume of foreign derivatives is a proxy variable of exchange rate derivatives. Previous findings have shown that in addition to risk mitigation, the use of foreign currency derivatives affects firm value. In this regard, Luo and Wang (2018) highlight that exposure is higher for firms with more significant profitability and evidence of top investment opportunities. On the other hand, some literature supports the idea that the effect of exchange rate derivatives on firm value is weaker during a crisis. The degree of exposure 
may explain those asymmetries. For example, Bae, Kim, and Kwon (2018) explain that highly exposed firms show lower firm risk but also lower firm values.

Regarding the effectiveness of foreign exchange derivatives in reducing exposure, Sikarwar (2018) found that since the financial crisis, firms are more exposed to exchange rate changes. Also, currency derivatives usage has been more productive during the crisis and post-crisis period, in contrast to the pre-crisis period. Likewise, some studies have analyzed the proper use of hedging strategies with derivatives. In a study that incorporates family ownership, Sikarwar and Gupta (2019) explain that the exposure increases for high and low levels of family ownership. Their findings reveal that under those circumstances, there is no proper use of hedging strategy with derivatives; meanwhile, for firms that exhibit middle levels of family ownership, foreign exchange hedging strategies are appropriately applied.

Regarding sales and purchases of foreign equity, Ozimkovska (2018) shows evidence of causality from real financial market exchange rate volatility to equity flows. The study also reveals that the real financial market exchange rate volatility negatively impacts purchases and sales of foreign equity. However, the effect of the real financial market exchange rate on net purchases of foreign equity impact is positive. In addition, their findings show that when foreign assets risk increases, sales of assets decrease sharply regarding purchases. The authors argue that their findings are consistent with the portfolio optimization theory, which is reviewed in the following section.

\subsection{International portfolio theory and foreign exchange derivatives}

International finance literature has highlighted the benefits of the foreign portfolio allocation, claiming that the optimal choice is the portfolio with the lowest spatiotemporal correlation with other markets. The theory also emphasizes that the exchange rate must be considered because it contributes to portfolio performance (Mo et al., 2019). Previous findings show that depending on the currency exchange rate correlations, foreign investors can benefit more than domestic investors from international trading. Branger, Muck, and Weisheit (2019) explain that correlations with the exchange rate can affect the utilities of foreign investors differently, while the impact of relationships between stocks can be symmetric. In that regard, Dwumfour and Addy (2019) found that only depreciation of the Ghana local currency against the U.S. dollar, but not against Britain Pounds or Euro, reduces the portfolio stock returns.

In this paper, in addition to performing an empirical analysis, the authors attempt to contribute to the literature by developing a theoretical model that helps to explain the moderating effect of foreign exchange derivatives on the exchange rate on a stock market relationship.

\section{Setting the Theoretical Model}

This analysis is based on Cox, Ingersoll and Ross (1985), with a general equilibrium theoretical model that incorporates asset prices. In order to relate a macroeconomic variable to financial assets, in the spirit of Bernal and Venegas-Martínez (2011) and Bakshi and Chen (1997), the model uses the exchange rate instead of the inflation rate as the underlying as- 
set of the derivative. The proposal is also similar to that of Venegas-Martínez (2006) which develops a stochastic model to deal with the uncertainty in the dynamic of the exchange rate.

For this research, the first assumption is to consider an economy populated with investors with the following utility function (preferences or tastes):

$$
U\left(t, c_{t}, c_{t}^{*}\right)=e^{-\delta t}\left[\varphi \ln \left(c_{t}\right)+(1-\varphi) \ln \left(c_{t}^{*}\right)\right],
$$

where $c_{t}$ and $c_{t}^{*}$ are the local and foreign consumption, respectively, $\delta$ is a time-invariant subjective discount rate (measuring impatience of consumption), and $\varphi$ is the utility share on the domestic goods. Moreover, the investors in this economy have access to a foreign stock, whose price is driven by the following first-order stochastic differential equation (geometric Brownian motion):

$$
\mathrm{d} S_{t}^{*}=S_{t}^{*}\left(\mu_{s} \mathrm{~d} t+\sigma_{s} \mathrm{~d} W_{s}\right)
$$

where $\mu_{s}$ and $\sigma_{s}$ are the drift and volatility parameters, respectively, and $W_{s}$ is a Brownian motion (perturbations with stationary and independent normally distributed increments with mean zero and variance $s$ ) defined on a fixed probability space $(\Omega, \mathcal{F}, P)$.

In order for the investors to be able to quantify their portfolio performance in local currency, this model presumes that the exchange rate follows:

$$
\mathrm{d} E_{t}=E_{t}\left(\mu_{e} \mathrm{~d} t+\sigma_{e} \mathrm{~d} W_{e}\right)
$$

where $E_{t}$ is the price of one unit of foreign currency in terms of local currency. As before, $\mu_{e}$ and $\sigma_{e}$ are the drift and volatility parameters of the foreign exchange rate. Consistent with traditional international finance theory, this investor is exposed to two exogenous sources of risk, the stock market risk driven by $W_{s}$ and the exchange rate risk driven by $W_{e}$. This means that to quantify the expected returns of this foreign asset, the investor should consider the expected return of the foreign asset plus the expected return of the exchange rate. The covariance between $\mathrm{d} W_{s}$ and $\mathrm{d} W_{e}$ is supposed to be given by:

$$
\operatorname{Cov}\left(\mathrm{d} W_{s}, \mathrm{~d} W_{e}\right)=\rho \mathrm{d} t
$$

where $\rho$ is the instantaneous correlation between $S_{t}^{*}$ and $E_{t}$. Also, investors incorporate exchange rate derivatives to minimize the exchange rate exposure. To a better understanding of the main purpose of the model, it helps to think of it as an Exchange Trade Fund (ETF), like the iShares Currency Hedged MSCI Eurozone, which aims to reduce the impact of the Eurodollar on the Eurozone stocks made up of Eurozone shares, EUR cash and EUR/USD forwards. This research assumes that the investors have access to a foreign exchange rate derivative driven by the following stochastic dynamic:

$$
\mathrm{d} X\left(E_{t}, t\right)=X_{t}\left(\mu_{x} \mathrm{~d} t+\sigma_{x} \mathrm{~d} W_{e}\right)
$$

where the drift is:

$$
\mu_{x}=\left[\frac{\partial X}{\partial t}+\frac{\partial X}{\partial E_{t}} \mu_{e} E_{t}+\frac{1}{2} \frac{\partial^{2} X}{\partial E^{2}} \sigma_{e}^{2} E_{t}^{2}\right] \frac{1}{X_{t}}
$$


and volatility satisfies

$$
\sigma_{x}=\frac{E_{t}}{X_{t}} \frac{\partial X}{\partial E} \sigma_{e}
$$

Since (5) is driven by $\mathrm{d} W_{e}$, it implies that $\rho$ is also the instantaneous correlation between $S_{t}^{*}$ and $X_{t}$. Moreover, investors hold a risk-free foreign asset, for example, a bond, of price $B_{t}^{*}$, that satisfies:

$$
\mathrm{d} B_{t}^{*}=i B_{t}^{*} \mathrm{~d} t
$$

where $i$ is the paid interest rate. Hence, the investor value function (economic welfare) from maximizing the expected utility is given by:

$$
J\left(t, a_{t}\right)=\max _{c_{t}, c_{t}^{*}, \theta_{s}^{*}, \theta_{x}} \mathrm{E}\left\{\int_{t}^{\infty} e^{-\delta s}\left[\varphi \ln \left(c_{s}\right)+\right] \mathrm{d} s \mid \mathcal{F}_{t}\right\},
$$

where $\theta_{s}^{*}$ and $\theta_{x}$ are the proportions of wealth invested in assets $S_{t}^{*}$ and $X_{t}$, respectively. $\mathcal{F}_{t}$ stands for all relevant information available at time $t$. The equation of wealth, $a_{t}$, of the representative consumer-investor is:

$$
a_{t}=S_{t}^{*} E_{t}+B_{t}^{*} E_{t}+X\left(E_{t}, t\right)-c_{t}-c_{t}^{*} E_{t} .
$$

where $S_{t}^{*} E_{t}, B_{t}^{*} E_{t}$ and $c_{t}^{*} E_{t}$ are the foreign asset price, the foreign bond price and the foreign consumption at time $t$, respectively, in terms of the local currency. Here, $X_{t}$ is the derivative price, and $c_{t}$ is the local consumption at time $t$. Therefore, the evolution of the marginal wealth accumulation follows:

$$
\mathrm{d} a_{t}=a_{t}\left[\theta_{s} \mathrm{~d} R_{s e}+\theta_{x} \mathrm{~d} R_{x}+\left(1-\theta_{s}^{*}-\theta_{x}\right) \mathrm{d} R_{b}-\frac{c_{t}}{a_{t}} \mathrm{~d} t-\frac{c_{t}^{*} E_{t}}{a_{t}} \mathrm{~d} t\right] .
$$

In the previous equation, $\mathrm{d} R_{s e}, \mathrm{~d} R_{x}$, and $\mathrm{d} R_{b}$ denote the rate of return of the foreign asset, the return derivative, and the return of the risk-free asset, respectively, all in local terms. The returns satisfy:

$$
\begin{gathered}
\mathrm{d} R_{s E}=\frac{\mathrm{d}\left(S_{t}^{*} E_{t}\right)}{S_{t}^{*} E_{t}}=\left(\mu_{S^{*}}+\mu_{e}+\rho\right) \mathrm{d} t+\sigma_{S^{*}} \mathrm{~d} W_{s}+\sigma_{e} \mathrm{~d} W_{e}, \\
\mathrm{~d} R_{x}(t)=\frac{\mathrm{d} X\left(E_{t}, t\right)}{X\left(E_{t}, t\right)}=\mu_{x} \mathrm{~d} t+\sigma_{x} \mathrm{~d} W_{e},
\end{gathered}
$$

and

$$
\mathrm{d} R_{b}(t)=\frac{\mathrm{d}\left(B_{t}^{*} E_{t}\right)}{B_{t}^{*} E_{t}}=\left(i+\mu_{e}\right) \mathrm{d} t+\sigma_{e} \mathrm{~d} W_{e} .
$$

After substituting these returns in the equation of marginal wealth, the result is:

$$
\mathrm{d} a_{t}=a_{t}\left[\mu_{a} \mathrm{~d} t+\sigma_{a s} \mathrm{~d} W_{s}(t)+\sigma_{a e} \mathrm{~d} W_{e}(t)\right],
$$

where: 


$$
\begin{gathered}
\mu_{a}=\theta_{s}\left(\mu_{s}+\rho-i\right)+\theta_{x}\left(\mu_{x}-\mu_{e}-i\right)+i+\mu_{e}-\frac{c_{t}}{a_{t}}-\frac{c_{t}^{*} E_{t}}{a_{t}} ; \\
\sigma_{a s}=\theta_{s} \sigma_{s} \\
\sigma_{a E}=\theta_{x}\left(\sigma_{x}-\sigma_{e}\right)+\sigma_{e} .
\end{gathered}
$$

The next step is to characterize the optimal decisions $c_{t}, c_{t}^{*}, \theta_{s}$ and $\theta_{x}$ under the assumption that financial markets clear. ${ }^{1}$

Proposition 1. In equilibrium, the expected excess return of the foreign asset is associated with the instantaneous changes in the exchange rate mean return and the excess return of the exchange rate derivatives as follows:

$$
\left(\mu_{s}-i\right)=\beta_{s e} \frac{\sigma_{e}}{\sigma_{S}} \frac{\epsilon_{x e}\left(\mu_{e}-1\right)}{\left(1-\epsilon_{x e}\right)}+\beta_{s x} \frac{\sigma_{x}}{\sigma_{S}} \frac{\left(\mu_{x}-i\right)}{\left(\dot{o}_{x e}-1\right)}, \text { for } \epsilon_{x e} \neq 1 .
$$

Where,

$$
\begin{gathered}
\beta_{s x}=\frac{\operatorname{Cov}\left(d S^{*}, d X\right)}{\sigma_{x}^{2}}, \quad \beta_{s e}=\frac{\operatorname{Cov}\left(d S^{*}, d E\right)}{\sigma_{e}^{2}}, \\
\epsilon_{x e}=\frac{E}{X} \frac{\partial X}{\partial E}, \quad \sigma_{x}=\frac{E}{X} \frac{\partial X}{\partial E} \sigma_{e} .
\end{gathered}
$$

For simplicity, it is assumed that: $\beta_{s x}=\beta_{s e}$. The implications of this assumption and the conditions under which the assumption could be modified are analyzed in section 3 of this paper.

Sketch of the proof of (14): In order to characterize the optimal solution of (7) subject to (8), it is convenient to rewrite the indirect utility function, or value function, at time $t$ as:

$$
\begin{aligned}
& J\left(t, a_{t}^{*}\right)=\max _{c_{t}, c_{t}^{*}, \theta_{s}, \theta_{x}} E\left\{\int_{t}^{t+d t} e^{-\delta s}\left[\varphi \ln \left(c_{s}\right)+(1-\varphi) \ln \left(c_{s}^{*}\right)\right] d s+\right. \\
& \left.\int_{t+d t}^{\infty} e^{-\delta s}\left[\varphi \ln \left(c_{s}\right)+(1-\varphi) \ln \left(c_{s}^{*}\right)\right] \mid \mathcal{F}_{t}\right\} .
\end{aligned}
$$

After applying the mean value theorem for integrals on the first term and using the Taylor theorem on the second term:

$$
0=\max _{c_{t}, c_{t}^{*}, \theta_{s}, \theta_{x}} E\left\{e^{-\delta s}\left[\varphi \ln \left(c_{t}\right)+(1-\varphi) \ln \left(c_{t}^{*}\right)\right] d t+o(d t)+d J\left(t, a_{t}\right)+o(d t) \mid \mathcal{F}_{t}\right\} .
$$

If in the previous equation, Itô's lemma is applied, taking expected values, dividing by $\mathrm{d} t$, and using the fact that $\mathrm{o}(\mathrm{d} t) / \mathrm{d} t \rightarrow 0$ when $\mathrm{d} t \rightarrow 0$, then we get:

$$
0=\max _{c_{t}, c_{t}^{*}, \theta_{s}, \theta_{x}}\left\{e^{-\delta s}\left(\varphi \ln \left(c_{t}\right)+(1-\varphi) \ln \left(c_{t}^{*}\right)\right)+\frac{\partial J}{\partial t}+\frac{\partial J}{\partial a_{t}} a_{t} \mu_{a}+\frac{1}{2} \frac{\partial^{2} J}{\partial a_{t}^{2}} a_{t}^{2}\left(\sigma_{a s}^{2}+\sigma_{a e}^{2}+2 \sigma_{a s} \sigma_{a e} \rho\right)\right\} .
$$

\footnotetext{
${ }^{1}$ See, for instance, Venegas-Martínez (2008) or Cox, Ingersoll and Ross (1985).
} 
Now, consider the following solution candidate to the above condition

$$
J\left(a_{t}, t\right)=e^{-\delta t}\left[\beta_{0}+\beta_{1} \ln \left(a_{t}\right)\right] .
$$

Hence, the Hamiltonian is given by:

$$
\begin{gathered}
\max _{c_{t}, c_{t}^{*}, \theta_{s}, \theta_{x}} H\left(c_{t}, c_{t}^{*}, \theta_{s}, \theta_{x}\right)=\max _{c(t), c^{*}, \theta_{s}, \theta_{x}}\left\{e ^ { - \delta t } \left(\varphi \ln \left(c_{t}\right)+\right.\right. \\
\left.(1-\varphi) \ln \left(c_{t}^{*}\right)\right)-\delta e^{-\delta t}\left(\beta_{0}+\beta_{1} \ln \left(a_{t}\right)\right)+ \\
\beta_{1} e^{-\delta t}\left(\theta_{s}^{*}\left(\mu_{s}+\rho-i\right)+\theta_{x}\left(\mu_{x}-\mu_{e}-i\right)+i+\mu_{e}-\frac{c_{t}}{a_{t}}-\frac{c_{t}^{*} E_{t}}{a_{t}}\right)- \\
\frac{1}{2} \beta_{1} e^{-\delta t}\left[\left(\theta_{s} \sigma_{s}\right)^{2}+\left(\begin{array}{c}
\left.\theta_{x}\left(\sigma_{x}-\sigma_{e}\right)+\sigma_{e}\right)^{2}+ \\
2 \rho\left(\theta_{s} \sigma_{s}\right)\left(\theta_{x}\left(\sigma_{x}-\sigma_{e}\right)+\sigma_{e}\right)
\end{array}\right]\right\}=0 .
\end{gathered}
$$

Differentiating the above first-order-condition with respect to $c_{t}, c_{t}^{*}, \theta_{s}, \theta_{x}$, the optimal decisions for the utility maximization problem is obtained:

$$
\begin{gathered}
c_{t}=\frac{\varphi a_{t}}{\beta_{1}} ; \\
c_{t}^{*}=\frac{(1-\varphi) a_{t}}{\beta_{1}} ; \\
\theta_{s}=\frac{\left(\mu_{s}+\rho-i\right)-\frac{\sigma_{x} \rho\left(\mu_{x}-\mu_{e}-i\right)}{\sigma_{x}-\sigma_{e}}}{\left(\rho^{2}-1\right) \sigma_{s}^{2}}
\end{gathered}
$$

and

$$
\theta_{x}=\frac{\sigma_{s}\left(\mu_{x}-\mu_{e}-i\right)-\sigma_{x} \rho\left(\mu_{s}-i+\rho\right)+\left(\rho^{2}-1\right) \sigma_{e}^{2} \sigma_{s}+\sigma_{e}\left(\rho\left(\mu_{s}-i+\rho\right)-\left(\rho^{2}-1\right) \sigma_{x} \sigma_{s}\right)}{\left(\rho^{2}-1\right)\left(\sigma_{x}-\sigma_{e}\right)^{2} \sigma_{s}} .
$$

Assuming that in equilibrium the financial markets clears $\left(\theta_{x}=\theta_{s}=0\right)$, given the definition of $\rho=\frac{\operatorname{Cov}\left(S_{t}^{*}, E_{t}\right)}{\sigma_{e} \sigma_{s}}$, and with algebraic manipulation of (22), the equation (14) is
obtained.

The intuition of the theoretical results is the following: First; equation (14) is the result of an optimization decision in a portfolio context where the economic agent takes optimal portfolio decisions, hedging the exchange rate risk with derivatives. Thus, the implications for this research are related to that context. Second, as Cuthbertson and Nitzsche (2004) explain for the CAPM model, equation (14) is not conceived as a predictive equation for the return of an asset because both variables are defined at the same time $t$. In this sense, equation (14) implies that the expected excess return of a foreign asset, $\mu_{s}$, is linked to both the instantaneous changes in the exchange rate, $\mu_{e}$, and the excess return of the exchange rate derivative, $\mu_{x}-i$. 
Second; equation (14) shows that the partial effect of the exchange rate on the expected foreign asset returns, $\mu_{s}-i$, is the parameter $\beta_{s e}$. If, for example, $\beta_{s e}<0$, it implies that an increase in the exchange rate return would harm stock returns. However, when portfolio managers incorporate derivatives for hedging purposes, equation (14) states that, under certain conditions, the partial effect of the exchange rate return could be compensated by incorporating a position in an exchange rate derivative. That condition is obtained by estimating the partial derivate of the excess return against the exchange rate return in (14), $\frac{\partial\left(\mu_{s}-i\right)}{\partial \mu_{e}}=0$. Using also the definition in (5.1), the result of that partial derivate is:

$$
\beta_{s e}=\beta_{s x} \epsilon_{x e} .
$$

The term $\epsilon_{x e}$ is equivalent to the minimum variance hedge ratio (Chen, Lee, \& Shrestha, 2003), which is frequently used in derivative pricing to estimate the number of units of the derivative to hedge the underlying asset. In the empirical section, this research exemplifies how that parameter could be applied in portfolio hedging strategies.

\section{Empirical research}

In this section, the previous analysis is used to test the magnitude and composition of the effect of the foreign exchange market on Mexican and Brazilian stock markets by testing equation (14). It is important to emphasize that measuring exchange rate exposure with operating cash flows may not be accurate, because operating cash flows may not account for operating derivatives (Bartram et al., 2011). Also, the theoretical model developed in this work is dynamic, so it is a necessary condition to perform the study with instantaneous changes in prices. Consequently, this work uses high frequency traded assets for the empirical analysis, like foreign exchange rate assets and stocks traded in the organized market. Thus, exchange rate exposure is measured as the regression coefficient of the exchange rate against the stock market (Adler \& Dumas, 1983; Hodder, 1982; Makar \& Huffman, 2008). Accordingly, to test the theoretical model, the empirical analysis follows the equation:

$$
R_{i t}-R_{f t}=\beta_{o, i}+\beta_{s e, i} E x c_{t}+\beta_{s x, i}\left(F u_{t}-R_{f t}\right)+\beta_{3, i}\left(R_{m, t}-R_{f t}\right)+u_{i, t} .
$$

The variable $R_{i t}$ is the daily return of the stock in day $t, R_{f t}$ is the risk-free rate, $E x c_{t}$ is the arithmetic return of the exchange rate. The variable $\left(F u_{t}-R_{f t}\right)$ is the excess return of currency derivative. Even when the analysis looks for testing the solution in equation (14), we control for market risk using the respective country's stock index, incorporating the term, $R_{m, t}-R_{f t}$, which is the market risk premium. For the exchange rate derivative prices, $F u_{t}$, we use the Chicago Mercantile Exchange (CME) futures on the Mexican Peso and Brazilian Real against the U.S. dollar. To keep track of exchange rate exposure, only companies with residence in the respective country were considered; then the firms' tickers were filtered by country of residence according to the Bloomberg database stock market screener. The arithmetic return was estimated from daily prices from 2007 to 2019. As a result, the model is on an unbalanced panel of 116 Mexican tickers and 207 Brazilians. The application Quantitative 
Financial Modelling Framework (Ryan et al., 2019) was used to gather stock prices and stock exchange indexes. As a risk-free rate, the short-term Treasury Bill rate from the respective central bank database was used. The exchange rates were taken as the spot exchange rate from the Bloomberg platform. In Appendix, descriptive statistics of the variables are presented. The panel data unit root tests were performed using several methods, and it was concluded that all variables are stationary, which is a statistical property to avoid spurious relationships.

For the statistical analysis, it must be considered that hedging decisions are correlated with size and leverage, as well as investment opportunities (Pérez-González \& Yun, 2013). Thus, hedging is endogenously determined. In the sample, there are significant differences in the size of the companies, which is a possible source of endogeneity. Another potential cause of endogeneity is the measurement error in the independent variable. So, panel data models can offer an adequate alternative to deal with these problems (Roberts \& Whited, 2012). Equation (25) is estimated in a panel data model using the GMM strategy. In addition to the two countries' independent analyses, we incorporate a third scenario that combines both countries, a panel data of 323 stocks.

Table 1. Panel estimation of equation (25)

\begin{tabular}{|l|c|c|c|c|c|c|}
\hline \multirow{2}{*}{} & \multicolumn{2}{|c|}{ Mexican case } & \multicolumn{2}{c|}{ Brazilian case } & \multicolumn{2}{c|}{$\begin{array}{c}\text { Mexican and Brazil } \\
\text { together }\end{array}$} \\
\cline { 2 - 7 } & $(1)$ & $(2)$ & $(3)$ & $(4)$ & $(5)$ & $(6)$ \\
\hline Exchange rate & $-0.160^{* * *}$ & $-0.071^{* * *}$ & $-0.098^{* * *}$ & $-0.030^{* *}$ & $-0.1037^{* * *}$ & $-0.0211^{* *}$ \\
\hline $\begin{array}{l}\text { Futures exchange } \\
\text { rate }\end{array}$ & & $-0.124^{* * *}$ & & $-0.091^{* * *}$ & & $-0.1095^{\star * *}$ \\
\hline $\begin{array}{l}\text { Market risk } \\
\text { premium }\end{array}$ & $0.676^{* * *}$ & $0.662^{* * *}$ & $0.497^{* * *}$ & $0.492^{* * *}$ & $0.5267^{* * *}$ & $0.5198^{* * *}$ \\
\hline Constant & $0.000^{* * *}$ & $0.000^{* * *}$ & $0.000^{* * *}$ & $0.000^{* * *}$ & $0.0004^{* * *}$ & $0.0003^{* * *}$ \\
\hline
\end{tabular}

Note: Dependent variable: stock excess return. Method: Panel Generalized Method of Moments, 2SLS instrument weighting matrix. Periods included: 3019 (Mexico) and 3036 (Brazil). Cross-sections included: 116 (Mexico), 207 (Brazil) and 323 (both). Unbalanced panel observations: 185,144 (Mexico), 458,884 (Brazil) 664,983 (both).

${ }^{* *}$ Significance at $1 \%$, and ${ }^{* *}$ at $5 \%$.

Columns 1, 3 and 5 of Table 1 show a negative and significant transmission from the foreign exchange market to the stock market, which is consistent with recent studies for emerging countries, including these two countries (Chkili, 2012; El Abed, 2017; SantillánSalgado et al., 2019). Second, in columns 2, 4, and 6, of Table 1, the parameters associated with the exchange rate futures return are incorporated. An evident conclusion from these results is that the coefficients associated with the exchange rate are lower for each scenario, compared with the scenario without the futures. In addition, the coefficients of the futures are also negative, significant, and larger than the exchange rate coefficient. This implies that the effect of the exchange rate on stock markets has two components, the spot exchange rate, and the futures market effect, both negative for Mexico and Brazil. For the three cases, the coefficient associated with the futures is greater than that of the exchange rate. Equation (24) 
explains that the minimum variance hedge ratio causes such a result because of the changes in the underlying asset causes the futures price variations. To prove that, the minimum variance hedge ratio parameter is estimated for the sample, according to the following equation:

$$
F u_{t}=\alpha_{o, i}+\epsilon_{x e} E x c_{t}+u_{i, t}
$$

Table 2. Estimation of equation (26)

\begin{tabular}{|l|c|c|c|}
\hline & $\begin{array}{c}\text { Mexican case } \\
(1)\end{array}$ & $\begin{array}{c}\text { Brazilian case } \\
(2)\end{array}$ & $\begin{array}{c}\text { Mexican and Brazil together } \\
(3)\end{array}$ \\
\hline Exchange rate & $0.777^{\star * \star}$ & $0.823^{\star * \star}$ & $0.813^{\star * \star}$ \\
\hline Constant & $0.000^{\star * \star}$ & $0.000^{* * *}$ & $0.000^{\star * \star}$ \\
\hline
\end{tabular}

Note: Dependent variable: Exchange rate futures return. Method: Least squares.

Periods included: 3019 (Mexico) and 3036 (Brazil). ${ }^{* \star *}$ Significance at 1\%.

For the Mexican case, using the results of column 2 in Table 1, we see that a $1.00 \%$ increase in the exchange rate would imply a decrease of $0.071 \%$ in stock prices. Likewise, because the hedge ratio is reflecting the elasticity of the futures price return concerning the spot exchange rate, Table 2, column 1, shows that the futures price would increase by $0.77 \%$, which would have an impact of $0.77 \%$ times the coefficient of the futures. As a result, the stock return would decrease by $0.0963 \%$. If we summarize the total effect of the two forces, it would be a decrease in the stock return of $0.1673 \%$, which is similar to the result of the parameter of the exchange rate in Table 1, column 1, which does not consider the effect of the exchange rate futures. The same applies to the Brazilian case and the panel for both countries, in which case the total impact would be $0.1049 \%$ and $0.1101 \%$ respectively, which is close to the coefficient of the spot exchange rate in columns 3 and 5 .

Finally, as an extension of the results in (14), an international portfolio strategy is applied to examine how to implement an optimal currency hedge. The application consists of estimating the proportion of currency futures to hedge the exchange risk of an international portfolio. The portfolio is a hypothetically dollar-based. It would incorporate stocks from Mexican and Brazilian stock markets, Mexican Peso, and Real Brazilian cash. Also, it would include a short position in exchange rate futures on the currencies of those countries against the U.S. dollar, to mitigate exchange rate exposure; that portfolio would be similar in its composition to the Eurozone iShares ETF mentioned before. For simplicity, the portfolio is assumed to be equally weighed.

Using only the minimum variance hedge ratio coefficient from equation (26) to estimate the proportion of futures contracts to hedge the portfolio would lead to a sub-optimal hedge. In that regard, based on the result of Table 2, column 3, it would imply shorting an amount equivalent to $81.3 \%$ of the portfolio value. However, in that case, based on column 6 of Table 1, a depreciation of the Mexican or Brazilian currency, which jointly implied a $1 \%$ of that currency depreciation, would lead to a decrease of $0.0211 \%$ of the portfolio value. Also, because of the positive correlation of the spot and futures, an increase in the futures price of $0.813 \%$ is expected, which implies a gain of $0.089 \%$ in portfolio value 
( $0.813 \%$ times the expected loss in the future contract of $10.95 \%)$. In that case, should the position in the currency futures had been $0.813 \%$ of the portfolio value, the gain required to hedge the position would have been overestimated by almost four times. Then, to make an optimal hedge, this research proposes using the result in equation (24), which implies taking a position of size: $\frac{\beta_{s e}}{\beta_{s x} \epsilon_{x e}}$. In terms of (14), that is the condition for a zero change in the portfolio return when the exchange rate changes. In that case, the position needed is short the exchange rate futures by $23.7 \%$ of the total exposure. That position would imply that given the change by $1 \%$ of the exchange rate, the position in the futures would generate a profit of $0.021 \%$ to compensate for the loss of the currency depreciation in the same amount. ${ }^{2}$

\section{Discussion}

Regarding the results for both sections, the theoretical model answers the research question of how the exchange rate derivatives are affecting the relationship between the exchange rate and stock markets. The findings suggest that the derivative markets are not necessarily contributing to lower the exchange rate exposure in the stock market. Still, it implies that to measure exchange rate exposure, we need to consider both the effect of the exchange rates and the foreign currency derivative effect. An implication of this result is suggested caution for traders, portfolio managers, and policymakers when estimating the exchange rate exposure in the financial market. It emphasizes the need to account for both sources of risk, and to make risk management adjustments in that sense. For example, currently, the Mexican central bank uses forwards by differences when the spot exchange rate volatility reaches a certain level. The latter suggests that that authority is not necessarily taking actions to manage the volatility of the more substantial source, or which could imply a more significant impact, in this case, the futures market. In that regard, further research is needed to analyze if the demand for foreign exchange futures goes down in response to increased volatility (Bhargava \& Malhotra, 2007). Also, the analytical result of this study supports the idea that the increases in dollar depreciation, relative to foreign currencies, are positively correlated with increases in the purchase of foreign exchange forwards (Hodrick \& Srivastava, 1986).

The empirical results of this study are consistent with recent evidence that shocks to the exchange rate volatility lead to increased hedging activity, and that futures contracts trading activity reflects additional speculation-type activity (Brown \& Curci, 2002). In this respect, the findings of this study contribute with a practical solution to mitigate exchange rate risk for a foreign asset portfolio. It accurately suggests a passive strategy to estimate the size of a futures contract to offset the exchange rate risk in international portfolios. This result contributes to solving the problem based on the evidence that novel financial assets, like ETFs, do not fully replicate the performance of their respective benchmarks (Almudhaf, 2019).

\footnotetext{
2 The increase in $1 \%$ of exchange rate would lead a change in the futures prices of $0.813 \%$, which would cause a change in the stock portfolio of $0.813 \%$ times $10.95 \%$, but if the position in futures is only of $23.7 \%$, then the portfolio would be compensated by an increase of $0.021 \%$.
} 


\section{Conclusions}

This article analyzes the effect of exchange rate markets on financial markets. For Brazilian and Mexican stocks, this study found that the negative impact of that relationship is composed of two factors, the exchange rate futures, and the spot exchange rate, where the effect of the derivative is almost five times the spot one. An explanation of that effect is associated with the minimum variance hedge ratio parameter, which measures the correlation between the derivative and the underlying asset. The result implies that if the spot exchange rate moves, the futures movements are in the same direction, but with a larger magnitude. The empirical analysis proves that results and also show that a currency depreciation in Mexico by $1 \%$ leads to a negative impact on the stock market by almost $0.16 \%$ daily. From which, $0.07 \%$ of that effect is from the spot market and $0.095 \%$ from the futures market. For the Brazilian case, the total impact is $0.09 \%$, mainly because of the futures market. However, under certain conditions, that feature offers an alternative to hedge the exchange rate risk using foreign futures. The importance of those results is because it extends the understanding of the sources of risk, and is aimed to help risk managers and policymakers to improve foreign currency risk management practices.

This research contributes to the literature that analyzes exchange rate exposure in the stock market, which also enhances the use of derivatives to promote financial system stability. Moreover, these findings support the arguments in favor of strategic positions in futures, which allow for higher gains while reducing risk conditions. It also offers a methodology for investors that proactively make a trade before large exchange rate movements in anticipation of changes in the exchange rate. Finally, the practical application presented in this study reinforces the idea that investors should only partially hedge the underlying currency risk. The limitation of this study is that the empirical analysis is applied only for foreign exchange futures and for Latin American economies. Further research is needed to analyze the effect of other derivatives, like options, and also extended the empirical analysis to other regions.

\section{References}

Adler, M. \& Dumas, B. (1983). International portfolio choice and corporation. finance: A synthesis. Journal of Finance, 38(3), 925-984. https://doi.org/10.1111/j.1540-6261.1983.tb02511.x

Allayannis, G. \& Ofek, E. (2001). Exchange rate exposure, hedging and the use of foreign currency derivatives. Journal of International Money and Finance, 2(2), 273-296. https://doi.org/10.1016/S0261-5606(00)00050-4

Almudhaf, F. (2019). Pricing efficiency of exchange traded funds tracking the gulf cooperation countries. Afro-Asian Journal of Finance and Accounting, 9(2), 117-140. https://doi.org/10.1504/AAJFA.2019.099485

Anderson, B. P., Makar, S. D., \& Huffman, S. H. (2004). Exchange rate exposure and foreign exchange derivatives: Do ineffective hedgers modify future derivatives use? Research in International Business and Finance, 18(2), 205-216. https://doi.org/10.1016/j.ribaf.2004.04.001

Anisak, N., \& Mohamad, A. (2019). Foreign exchange exposure of Indonesian listed firms. Global Business Review. https://doi.org/10.1177/0972150919843371 
Aysun, U. \& Guldi, M. (2011). Derivatives market activity in emerging markets and exchange rate exposure. Emerging Markets Finance and Trade, 47(6), 46-67.

https://doi.org/10.2753/REE1540-496X470603

Bae, S. C., Kim, H. S., \& Kwon, T. H. (2018). Currency derivatives for hedging: New evidence on determinants, firm risk, and performance. Journal of Futures Markets, 38(4), 446-467. https://doi.org/10.1002/fut.21894

Bakshi, G. S., \& Chen, Z. (1997). Equilibrium valuation of foreign exchange claims. Journal of Finance, 52(2), 799-826. https://doi.org/10.2307/2329499

Bartram, S., Brown, G., \& Conrad, J. (2011). The effects of derivatives on firm risk and value. Journal of Financial and Quantitative Analysis, 46(4), 967-999. https://doi.org/10.1017/S0022109011000275

Bernal, L., \& Venegas-Martínez, F. (2011). Impacto de los productos derivados los objetivos de política monetaria: un modelo de equilibrio general. Estudios Económicos, 26(2), 187-216.

Bhargava, V., \& Malhotra, D. K. (2007). The relationship between futures trading activity and exchange rate volatility, revisited. Journal of Multinational Financial Management, 17(2), 95-111. https://doi.org/10.1016/j.mulfin.2006.05.001

Branger, N., Muck, M., \& Weisheit, S. (2019). Correlation risk and international portfolio choice. Journal of Futures Markets, 39(1), 128-146. https://doi.org/10.1002/fut.21941

Brown, C. J., \& Curci, R. (2002). Mexican peso futures and exchange rate volatility. Latin American Business Review, 3(1), 75-90. https://doi.org/10.1300/J140v03n01_04

Caves, R. E. (2007). Multinational enterprise and economic analysis. Cambridge University Press. https://doi.org/10.1017/СBO9780511619113

Chen, S.-S., Lee, C.-f., \& Shrestha, K. (2003). Futures hedge rations: A review. Quarterly Review of Economics and Finance, 43(3), 433-465. https://doi.org/10.1016/S1062-9769(02)00191-6

Chkili, W. (2012). The dynamic relationship between exchange rates and stock returns in emerging countries: Volatility spillover and portfolio management. International Journal of Management Science and Engineering Management, 7(4), 253-262. https://doi.org/10.1080/17509653.2012.10671230

Cox, J. C., Ingersoll, J. E., \& Ross, S. A. (1985). An intertemporal general equilibrium model of asset prices. Econometrica, 53(2), 363-384. https://doi.org/10.2307/1911241

Cuthbertson, K., \& Nitzsche, D. (2004). Quantitative financial economics. Wiley.

Demange, G., \& Laroque, G. (1999). Efficiency and options on the market index. Economic Theory, 14(1), 227-235. https://doi.org/10.1007/s001990050290

Duarte, J. B., \& Mascareñas, J. M. (2014). Comprobación de la eficiencia débil en los principales mercados financieros latinoamericanos. Estudios Gerenciales, 30(133), 365-375. https://doi.org/10.1016/j.estger.2014.05.005

Dwumfour, R. A., \& Addy, N. A. (2019). Interest rate and exchange rate exposure of portfolio stock returns: Does the financial crisis matter? Journal of African Business, 20(3), 339-357. https://doi.org/10.1080/15228916.2019.1583977

El Abed, R. (2017). Exploring the nexus between stock prices and macroeconomic shocks: Panel VAR approach. Economics Bulletin, 37(3).

Guay, W., \& Kothari, S. P. (2003). How much do firms hedge with derivatives? Journal of Financial Economics, 70(3), 423-461. https://doi.org/10.1016/S0304-405X(03)00179-X

He, J., \& Ng, L. (1998). The foreign exchange exposure of Japanese multinationals corporations. The Journal of Finance, 53(2), 733-753. https://doi.org/10.1111/0022-1082.295575

Hodder, J. E. (1982). Exposure to exchange-rate movements. Journal of International Economics, 13(34), 375-386. https://doi.org/10.1016/0022-1996(82)90065-4

Hodrick, R. J., \& Srivastava, S. (1986). The covariation of risk premiums and expected future spot exchange rates. Journal of International Money and Finance, 5(1), S5-S21.

https://doi.org/10.1016/0261-5606(86)90015-X 
Inci, A. C., \& Lee, B. S. (2014). Dynamic relations between stock returns and exchange rate changes. European Financial Management, 20(1), 71-106. https://doi.org/10.1111/j.1468-036X.2011.00621.x

Jorion, P. (1990). The exchange-rate exposure of U.S. Multinationals. Journal of Business, 63(3), 331-345. https://doi.org/10.1086/296510

Kambi, K., \& Ali, A. I. (2016). Effects of financial risk management practices on financial performance of listed banks at the Nairobi securities exchange in Kenya. International Journal of Business and Management, 4(4), 19-36.

Lee, B., \& Suh, J. (2012). Exchange rate changes and the operating performance of multinationals. European Financial Management, 18(1), 88-116. https://doi.org/10.1111/j.1468-036X.2009.00522.x

Luo, H. R., \& Wang, R. (2018). Foreign currency risk hedging and firm value in china. Journal of Multinational Financial Management, 47(48), 129-143. https://doi.org/10.1016/j.mulfin.2018.11.002

Mahapatra, S., \& Bhaduri, S. N. (2019). Dynamics of the impact of currency fluctuations on stock markets in india: Assessing the pricing of exchange rate risks. Borsa Istanbul Review, 19(1), 15-23. https://doi.org/10.1016/j.bir.2018.04.004

Makar, S., \& Huffman, S. (2008). UK multinationals' effective use of financial currency-hedge techniques: Estimating and explaining foreign exchange exposure using bilateral exchange rates. Journal of International Financial Management and Accounting, 19(3), 219-235. https://doi.org/10.1111/j.1467-646X.2008.01022.x

Mo, G., Tan, C., Zhang, W., \& Liu, F. (2019). International portfolio of stock indices with spatiotemporal correlations: Can investors still benefit from portfolio, when and where? North American Journal of Economics and Finance, 47, 168-183. https://doi.org/10.1016/j.najef.2018.12.002

Nguyen, H., Faff, R., \& Marshall, A. (2007). Exchange rate exposure, foreign currency derivatives and the introduction of the euro: French evidence. International Review of Economics and Finance, 16(4), 563-577. https://doi.org/10.1016/j.iref.2006.01.002

Ozimkovska, V. (2018). Real financial market exchange rate volatility and portfolio flows. International Economics and Economic Policy, 15(2), 281-303. https://doi.org/10.1007/s10368-017-0405-3

Pérez-González, F., \& Yun, H. (2013). Risk management and firm value: Evidence from weather derivatives. The Journal of Finance, 68(5), 2143-2176. https://doi.org/10.1111/jofi.12061

Roberts, M. R., \& Whited, T. (2012). Endogeneity in empirical corporate finance. In G. Constantinides, M. Harris, \& R. Stulz (Eds.), Handbook of the economics of finance (Vol. 2). Elsevier.

Rossi, J. L. (2011). Exchange rate exposure, foreign currency debt, and the use of derivatives: Evidence from Brazil. Emerging Markets Finance and Trade, 47(1), 67-89. https://doi.org/10.2753/REE1540-496X470104

Ryan, J., Ulrich, J., Thielen, W., Teetor, P., \& Bronder, S. (2019). Quantitative Financial Modelling Framework. R package version 0.4-15. https://cran.r-project.org/web/packages/quantmod/quantmod.pdf

Salma, U., \& Hussain, A. (2018). A comparative study on corporate diversification and firm performance across South Asian Countries. Journal of Accounting and Marketing, 7(1), 263-269. https://doi.org/10.4172/2168-9601.1000263

Santillán-Salgado, R. J., Núñez-Mora, J. A., Aggarwal, R., \& Escobar-Saldivar, L. J. (2019). Exchange rate exposure of Latin American firms: Empirical evidence. Journal of Multinational Financial Management, 51, 80-97. https://doi.org/10.1016/j.mulfin.2019.03.001

Sikarwar, E. (2018). Exchange rate fluctuations and firm value: Impact of global financial crisis. Journal of Economic Studies, 45(6), 1145-1158. https://doi.org/10.1108/JES-02-2017-0048

Sikarwar, E., \& Gupta, R. (2019). Economic exposure to exchange rate risk and financial hedging: Influence of ownership as a governance mechanism. Journal of Economic Studies, 46(4), 965-984. https://doi.org/10.1108/JES-10-2017-0286

Singh, G. (2017). Estimating optimal hedge ratio and hedging effectiveness in the NSE index futures. Jindal Journal of Business Research, 6(2), 108-131. https://doi.org/10.1177/2278682117715358 
Tang, B. (2019). Does the currency exposure affect stock returns of Chinese automobile firms? Empirical Economics, 57(1), 53-77. https://doi.org/10.1007/s00181-018-1437-4

Venegas-Martínez, F. (2006). Stochastic temporary stabilization: Undiversifiable devaluation and income risks. Economic Modelling, 23(1), 157-173. https://doi.org/10.1016/j.econmod.2005.09.004

Venegas-Martínez, F. (2008). Riesgos financieros y económicos: Productos derivados y decisiones económicas bajo incertidumbre (2 ed.). Cengage Learning.

Wei, K., \& Starks, L. (2013). Foreign exchange exposure elasticity and financial distress. Financial Management, 42(4), 709-735. https://doi.org/10.1111/fima.12016

\section{APPENDIX}

\section{Descriptive statistics of the empirical analysis variables}

Mexican case

\begin{tabular}{|l|c|c|c|c|c|}
\hline & Futures & Stock index & Risk free rate & Return of stock & Exchange rate \\
\hline Mean & $0.021 \%$ & $0.014 \%$ & $0.021 \%$ & $0.049 \%$ & $0.025 \%$ \\
\hline Median & $-0.033 \%$ & $0.035 \%$ & $0.018 \%$ & $0.000 \%$ & $-0.011 \%$ \\
\hline Maximum & $7.980 \%$ & $10.310 \%$ & $0.034 \%$ & $293.803 \%$ & $7.651 \%$ \\
\hline Minimum & $-5.755 \%$ & $-7.008 \%$ & $0.010 \%$ & $-99.088 \%$ & $-4.588 \%$ \\
\hline Std. Dev. & $0.798 \%$ & $1.134 \%$ & $0.007 \%$ & $3.212 \%$ & $0.752 \%$ \\
\hline Skewness & $82.593 \%$ & $-0.719 \%$ & $31.537 \%$ & $1154.513 \%$ & $111.820 \%$ \\
\hline Observations & 185,144 & 185,144 & 185,144 & 185,144 & 185,144 \\
\hline
\end{tabular}

Brazilian case

\begin{tabular}{|l|c|c|c|c|c|}
\hline & Futures & Exchange rate & Stock index & Risk free rate & Return of stock \\
\hline Mean & $0.03 \%$ & $0.03 \%$ & $0.04 \%$ & $0.04 \%$ & $0.07 \%$ \\
\hline Median & $0.00 \%$ & $0.00 \%$ & $0.05 \%$ & $0.04 \%$ & $0.00 \%$ \\
\hline Maximum & $7.68 \%$ & $7.37 \%$ & $13.43 \%$ & $0.06 \%$ & $124.50 \%$ \\
\hline Minimum & $-8.64 \%$ & $-5.79 \%$ & $-11.39 \%$ & $0.02 \%$ & $-53.72 \%$ \\
\hline Std. Dev. & $1.06 \%$ & $1.07 \%$ & $1.66 \%$ & $0.01 \%$ & $4.22 \%$ \\
\hline Skewness & $46.80 \%$ & $38.78 \%$ & $-0.09 \%$ & $-7.46 \%$ & $444.14 \%$ \\
\hline Observations & 459,113 & 459,113 & 459,113 & 459,113 & 459,113 \\
\hline
\end{tabular}

Mexican and Brazilian cases

\begin{tabular}{|l|c|c|c|c|c|}
\hline & Exchange rate & Futures & Stock index & $\begin{array}{c}\text { Return of } \\
\text { stock }\end{array}$ & Risk free rate \\
\hline Mean & $0.03 \%$ & $0.03 \%$ & $0.03 \%$ & $0.07 \%$ & $0.04 \%$ \\
\hline Median & $0.00 \%$ & $0.00 \%$ & $0.04 \%$ & $0.00 \%$ & $0.03 \%$ \\
\hline Maximum & $7.65 \%$ & $7.98 \%$ & $13.43 \%$ & $293.80 \%$ & $0.06 \%$ \\
\hline Minimum & $-5.79 \%$ & $-8.64 \%$ & $-11.39 \%$ & $-99.09 \%$ & $0.01 \%$ \\
\hline Std. Dev. & $0.99 \%$ & $0.99 \%$ & $1.53 \%$ & $3.96 \%$ & $0.01 \%$ \\
\hline Observations & 644,257 & 644,257 & 644,257 & 644,257 & 644,257 \\
\hline
\end{tabular}




\section{Correlation matrix of the empirical analysis variables}

Mexican case

\begin{tabular}{|l|c|c|c|c|c|}
\hline & FU & IPC & RF & REND & EXC \\
\hline FU & 1.0000 & -0.4472 & -0.0116 & -0.1478 & 0.7396 \\
\hline IPC & -0.4472 & 1.0000 & -0.0305 & 0.2540 & -0.3965 \\
\hline RF & -0.0116 & -0.0305 & 1.0000 & -0.0189 & -0.0044 \\
\hline REND & -0.1478 & 0.2540 & -0.0189 & 1.0000 & -0.1322 \\
\hline EXC & 0.7396 & -0.3965 & -0.0044 & -0.1322 & 1.0000 \\
\hline
\end{tabular}

Brazilian case

\begin{tabular}{|l|c|c|c|c|c|}
\hline & FU & EXC & IPC & RF & REND \\
\hline FU & 1 & 0.82356285 & -0.4677921 & -0.006637 & -0.119736 \\
\hline EXC & 0.82356285 & 1 & -0.5261331 & -0.0004968 & -0.1283132 \\
\hline IPC & -0.4677921 & -0.5261331 & 1 & -0.0061202 & 0.20847885 \\
\hline RF & -0.006637 & -0.0004968 & -0.0061202 & 1 & -0.0021915 \\
\hline REND & -0.119736 & -0.1283132 & 0.20847885 & -0.0021915 & 1 \\
\hline
\end{tabular}

Mexican and Brazilian cases

\begin{tabular}{|l|c|c|c|c|c|}
\hline & FU & EXC & IPC & RF & REND \\
\hline FU & 1 & 0.82356285 & -0.4677921 & -0.006637 & -0.119736 \\
\hline EXC & 0.82356285 & 1 & -0.5261331 & -0.0004968 & -0.1283132 \\
\hline IPC & -0.4677921 & -0.5261331 & 1 & -0.0061202 & 0.20847885 \\
\hline RF & -0.006637 & -0.0004968 & -0.0061202 & 1 & -0.0021915 \\
\hline REND & -0.119736 & -0.1283132 & 0.20847885 & -0.0021915 & 1 \\
\hline
\end{tabular}

